\title{
Natural capital: The limiting factor
}

James Aronson $^{\mathrm{a}, \mathrm{b}}$, James N. Blignaut ${ }^{\mathrm{c}}$, Sue J. Milton ${ }^{\mathrm{d}, \mathrm{e}}$ and Andre F. Clewell

${ }^{\text {a } R e s t o r a t i o n ~ E c o l o g y ~ G r o u p, ~ C e n t r e ~ d ' E c o l o g i e ~ F o n c t i o n n e l l e ~ e t ~ E v o l u t i v e ~(C N R S-~}$ UMR 5175), 1919, Route de Mende, 34293 Montpellier, France

${ }^{\mathrm{b}}$ Missouri Botanical Garden, USA

${ }^{\mathrm{c}}$ Department of Economics, University of Pretoria, Lynnwood Road, Pretoria 0002, South Africa

${ }^{\mathrm{d} C o n s e r v a t i o n ~ E c o l o g y ~ D e p a r t m e n t, ~ U n i v e r s i t y ~ o f ~ S t e l l e n b o s c h, ~ S o u t h ~ A f r i c a ~}$ ${ }^{\mathrm{e}}$ The FitzPatrick Institute, University of Cape Town, South Africa

${ }^{\mathrm{f}}$ A. F. Clewell Inc., 5351 Gulf Drive \#5, Holmes Beach, FL 34217-1954, USA

\section{Article Outline}

1. Introduction

2. Dialoguing with Daly and Farley

3. Conclusion

Acknowledgements

References

\section{Introduction}

The global economy is approaching crisis because of our neglect and misuse of the ecosystems that sustain us. Ecological overshoot of the globe's economy is an indisputable reality (Wackernagel et al., 2002). The Millennium Ecosystem Assessment (MEA) concluded that humans over the past few decades have changed ecosystems more rapidly and extensively than in any comparable period of time in human history. The challenge of slowing down, but preferably reversing, the degradation of ecosystems, while simultaneously meeting increasing human demands for energy, food, and ecosystem services requires significant changes in policies, 
institutions, and practices that are not currently under way (MEA, 2005). In other words, radical changes away from 'business as usual' or, better expressed, 'dynamics as usual' are needed.

The search for appropriate, feasible, yet effective turnkey strategies to mitigate and even overturn the negative environmental effects of the 20th century's growth path is therefore essential. In search for such a strategy, global analyst Lester Brown suggests a three-prong strategy to achieve sustainability, namely:

Sustaining our early 21st century global civilization now depends on shifting to a renewable energy-based, reuse/recycle economy with a diversified transport system. Business as usual - Plan A - cannot take us where we want to go. It is time for Plan B, time to build a new economy and a new world. Plan B has three components: (1) a restructuring of the global economy so that it can sustain civilization; (2) an all-out effort to eradicate poverty, stabilize population, and restore hope in order to elicit participation of the developing countries; (3) a systematic effort to restore natural systems (Brown, 2006).

Although we support Brown's first two strategies to restructure the economy and to augment social capital, we consider it of primary significance that he highlights, as his third point, the restoration of natural systems, also called the restoration of natural capital. The restoration of natural capital, as promoted by the convergent disciplines of restoration ecology and ecological engineering, is the only strategy that attempts to augment the world's rapidly dwindling stocks and resources of natural capital. Examples of such augmentation abound (Mitsch and Day, 2006, Lewis, 2005 and Mitsch et al., 2002). Such investments in natural capital are essential since natural capital (in a collective sense) is becoming increasingly a limiting factor to human well-being and economic sustainability. Ecological economist Herman Daly succinctly framed this proposition that natural capital is the limiting factor to development (and therefore in need of augmentation) when he wrote (personal communication, 25 January 2005):

More and more, the complementary factor in short supply (limiting factor) is remaining natural capital, not manmade capital as it used to be. For example, populations of fish, not fishing boats, limit fish catch worldwide. Economic logic says to invest in the limiting factor. That logic has not changed, but the identity of the limiting factor has. 
The strategic and economic importance of the restoration of natural capital through either ecological restoration or ecological engineering is further emphasised by the fact that such an activity is an acknowledgment that people are part of the ecosystem. Restoration provides an antithesis to the prevailing thesis of consumption and/or domination/subjugation of nature as way of life. The realization that nature sustains economies is, however, not new to ecologists. Leopold (1949) wrote on that theme, and subsequent authors have tried to impress it upon a broad audience (Hey et al., 2005, Hackney, 2000, Gren, 1995 and Storer, 1968). Ecologists have subsequently tried to develop a compelling empirical basis for the worth of natural capital that economists would accept (Odum, 1994 and Westman, 1977). The notion that ecological restoration could be applied as a remedy to the destruction of ecosystems was suggested by Cairns (1993) and Wyant et al. (1995), and specifically introduced to restoration ecologists by Clewell (2000) and further supported by ecological engineers (Lewis, 2005, Kangas, 2004, Mitsch and Jorgensen, 2004, Todd et al., 2003, Hackney, 2000 and Cairns, 2000).

The restoration of natural capital has therefore become an economic problem solving activity and should no longer be considered optional or a peripheral activity. The restoration of natural capital has become mainstream business in the quest for managing human-dominated ecosystems from within, meaning considering people part and parcel of the larger ecosystem and biosphere.

\section{Dialoguing with Daly and Farley}

The importance of restoration is now a foregone conclusion as discussed above, but it is important to engage with ecological economists, who can speak the language of both ecologists and economist, to propel the subject further, examples of which exist already (Fonseca et al., 2000 and Ton et al., 1998). Ecologists, especially restorationists, can contribute significantly to the process by helping ecological economists sharpen the models with which they communicate with the broader economics community. Our specific task in this paper is to dialog with two leading ecological economists, namely, Herman Daly and Joshua Farley, concerning one of the key conceptual figures in their recent, outstanding textbook, Ecological Economics (Daly and Farley, 2004). 
In the early pages of their textbook, Daly and Farley (2004) reproduce the well-known neoclassical economics double-loop circular flow diagram, with the first loop being the flow of goods and services from firms to households and payments for these goods and services flowing back in the opposite direction, and with labour and compensation therefore comprising the second loop. After criticizing this framework, Daly and Farley (2004) offer a different conceptual diagram, which contrasts a formerly 'empty' World with the currently over-crowded or 'full' World, as seen from an economic point of view (cf. Daly and Cobb, 1989 and Costanza, 1991). This diagram, redrawn below as Fig. 1, is clearly a huge advance over the neoclassical, closed-system, double-loop model. However, we find several points that deserve discussion:

1. The term 'ecosystem' is unnecessarily vague and reductionistic, and should be replaced by 'Biosphere'.

2. The relative thickness of the arrows leading from natural capital ('ecosystem') and Man-made capital ('economy') to 'welfare' (i.e., human welfare) in the two portions of the figure should not change so drastically. The figure suggests that in the formerly 'empty' world, ecosystem goods and services contributed much to welfare and economic services relatively little, while in our contemporary 'full' world, the situation is reversed. We question whether such a radical change has actually taken place, and would argue instead that growing economic services have made possible huge increases in human numbers but not, on average, human welfare. The human population has grown, as has the proportion that can be classified as ecological refugees (see below).

3. We prefer using the term manufactured to manmade capital simply to emphasise the fact that fixed capital stock (in economic terms) is converted or produced capital and does not have the ability to reproduce or sustain itself. It is biologically sterile. 4. Human welfare should not be situated outside the global ecosystem or biosphere, which implies that it becomes largely a psychic phenomenon once basic subsistence needs are met (Farley, personal communication). We argue it should be depicted within the Biosphere, as humans are - for better and for worse - a part of Nature, and should not be tempted or encouraged to forget it.

5. The terms 'empty' and 'full' are compelling and by now well known. However, more appropriate terminology would be 'underdeveloped' and 'overdeveloped', or something even more precise still (see below). 
6. Globalisation of markets is not mentioned.

7. To promote discussions of restoration between ecologists and economists, we prefer references to the stocks and values of natural capital, and the costs of ecological restoration.

8. By only focussing on an 'empty' versus 'full' world, one tends to be confronted by the problem only and not the strategy to offset the negative environmental effects of living in a 'full world'.

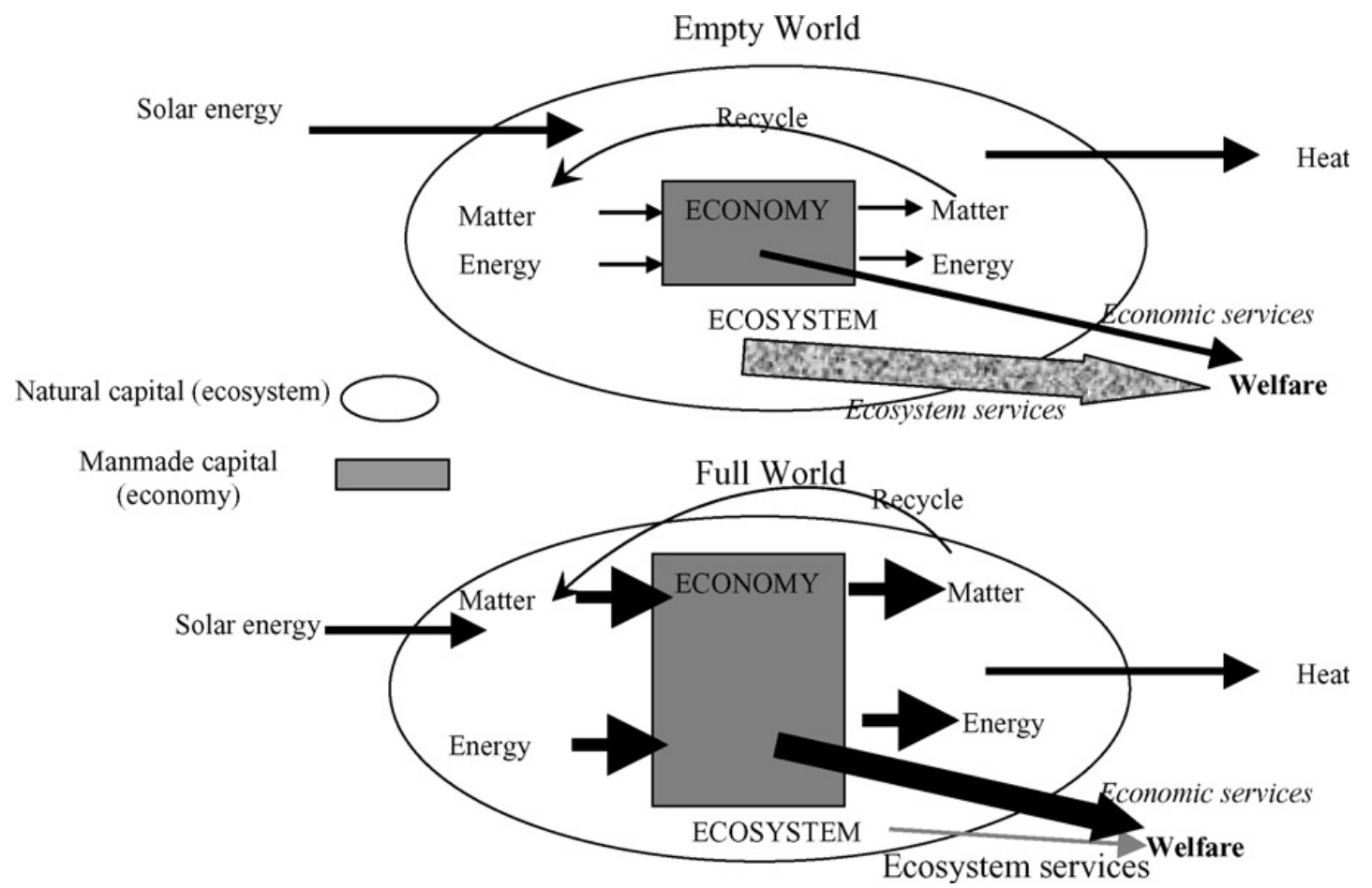

Fig. 1. Empty and full world diagrams, redrawn from Daly and Farley (2004) with permission of the authors and the publisher. A typographical error in the original “Natural capital (economy), Man-made capital (ecosystem)” has been corrected in this version with permission of the authors.

In Fig. 2, we offer a complementary figure to that of Daly and Farley's pair of conceptual diagrams in which we attempt to incorporate all eight of the points raised above and, simultaneously, to introduce the term 'Restoring Natural Capital' and, with it, the science and practice of ecological restoration and of ecological engineering. In this way we internalise - to borrow a term from economics - both 
restoration and ecological engineering as part of our professional response to the problems facing global society.
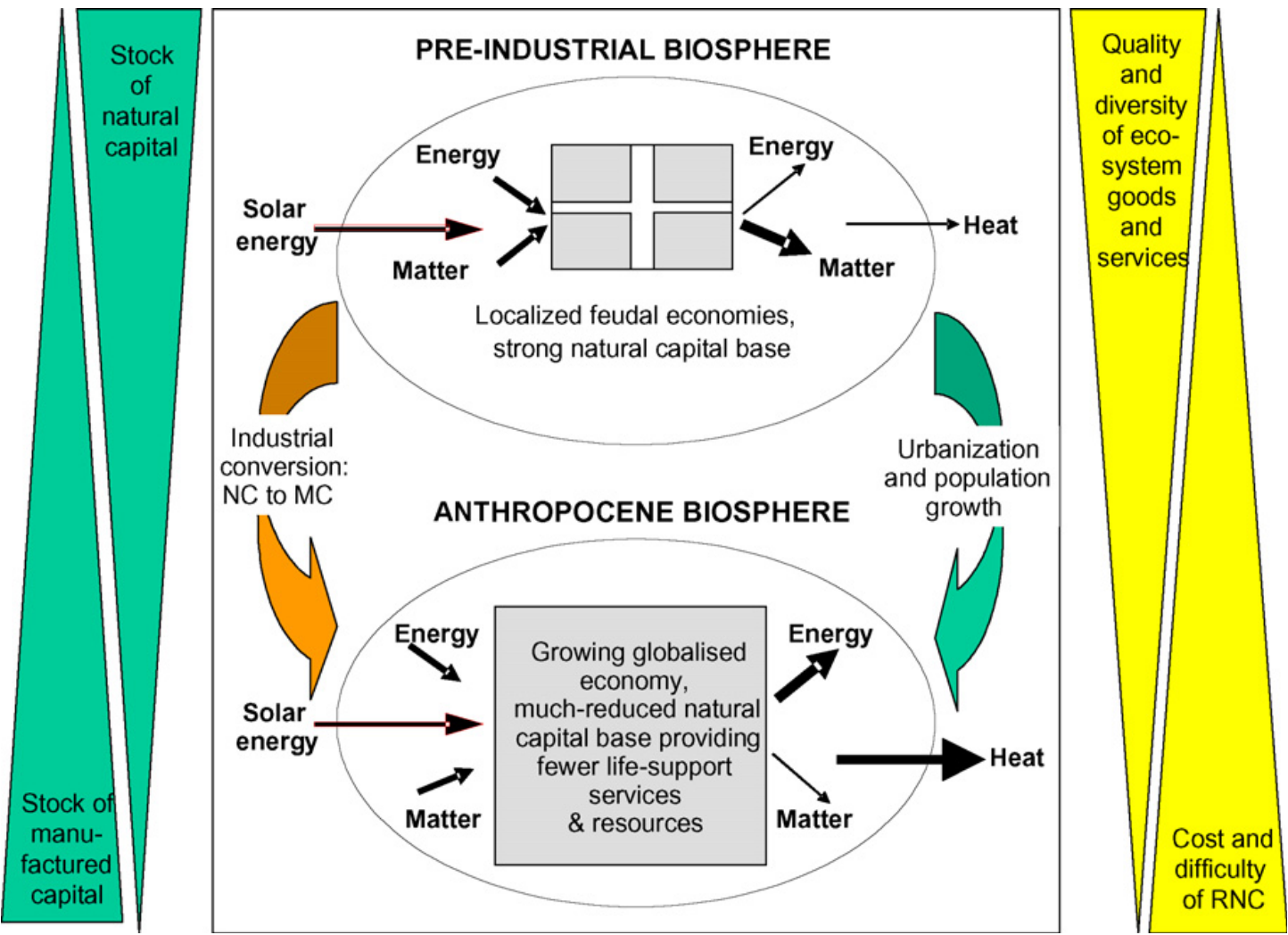

Fig. 2. Pre-industrial and anthropocene biospheres diagram. Note that in the anthropocene biosphere a relatively lower proportion of energy is contained in matter on earth (e.g., forests) with the balance leaving earth as heat or accumulating in the atmosphere as carbon dioxide. RNC stands for Restoring Natural Capital.

Firstly, note that the empty world and full world concepts have been transformed to a more specific comparison of the pre-industrial (i.e., prior to the mid-18th century) and the current 'anthropocene' biosphere. It was Nobel laureate Paul Crutzen (2002) who suggested the term 'anthropocene era' as the period since the invention of the dual action steam engine in 1784 , a date that is remarkably close to 1776 , the year in which Adam Smith published his Wealth of Nations, in which were introduced the ideas of free markets and the 'invisible hand'. It was the invention of a reliable steam engine that jumpstarted the industrial revolution and concomitant worldwide urbanisation (also see Ruddiman, 2003). This also led to an exponential increase in the use of oil and coal as compared to the pre-industrial era when wood was the primary source of energy. 
In the pre-industrial biosphere diagram (Fig. 2, top), we identify small, but localised (or relatively isolated) feudal economies, which were characterised by the relatively limited conversion of energy and matter to alternative forms (with lower levels of entropy) as well as heat. These economies, though resource-based, were supported by an extensive pool of natural capital stock. Since the inception of the industrial, or 'anthropocene' era, the rate of converting natural capital (NC) to manufactured capital (MC) has accelerated drastically. This increased rate of conversion (indicated by the thick arrows) not only enabled but also promoted urbanisation, resulting in the growth in human population. Rapid growth in urban populations increased the demand for produce from outside the periphery of the city. The ecological footprint of the city (and country) now increasingly reaches far beyond its own borders. This is the genesis of the globalised economy that depends on resources from elsewhere to survive and accommodate its market demands. Increased trade and resource demand are placing huge and ever-increasing pressures on the natural capital stock to provide essential life support services and resources. It has also led to a huge increase in what Gadgil (1995) called 'ecological refugees', and also 'biosphere people', and an equally alarming decrease in 'ecosystem people' (cf. Dasmann, 1972), all of which have potentially deleterious effects as well.

Finally, on the left hand side of Fig. 2, we compare the relative levels of natural and manufactured capital stock during the pre-industrial and anthropocene periods. On the right hand side of the figure, we indicate the inverse relationship that prevails, over the period of transition to the anthropocene era, between the quality and diversity of ecosystem goods and services, and the relative cost of restoring natural capital.

\section{Conclusion}

In this brief commentary, we have noted the reality that dwindling natural capital effectively limits economic growth globally. This warrants investment in the limiting factor (natural capital) through ecological restoration and ecological engineering. The consequences of dwindling natural resources are increasingly widespread and the impacts are increasingly, disturbingly profound and far-reaching. Restoration and creation of ecosystems is costly - and this is where an understanding of economics, the study of scarcity, can and should address the growing rarity and precarious health of natural and semi-natural systems. However, the costs to human society and 
economies of degraded, damaged, fragmented and destroyed ecosystems are much greater still. Instead of assets, in fact they often become liabilities.

For economists and ecologists to find common ground and to work together to develop new strategies for sustainability, the links between restoration ecology, ecological engineering and ecological economics should be both conceptually sound and practical, as tested and demonstrated through case studies. It is in this light that we have engaged with Daly and Farley here. We have sought to present a new perspective regarding the interplay between natural and manufactured capital on the one hand and restoration and the quality and diversity of ecosystem goods and services on the other. These are terms both ecologists and economists understand and which could become keystones in future intellectual development in the hybrid world that emerges when the two disciplines agree to come, or rather to jump together, to borrow a phrase from Wilson (1998).

Experience around the world (e.g., Janzen, 2002) has shown that, although restoration of extinct species is impossible, it is still feasible to restore much of the natural capital that we have damaged or lost. However, doing so will require more than advances in the science and technology of restoration itself. Just as conserving what remains of 'wild' nature now appears as common sense to anyone who has read Balmford et al. (2002), so restoring natural capital could one day emerge as a vital strategy for sustainability of biodiversity and human welfare (Clewell and Aronson, 2006). This in turn will require new ways of thinking, conceptualising and behaving. As Schumacher (1973) wrote:

Any intelligent fool can make things bigger, more complex and more violent. It takes a touch of genius - and a lot of courage - to move in the opposite direction.

But to move in that 'opposite direction' will become possible only when global society internalises the natural capital concept, and recognizes that natural capital is increasingly a limiting factor to our growth, development and well being. Such recognition would have immediate and radical impact on the pricing of goods and services derived from natural capital, as well as the cost of pollution, and on the profitability of ecological restoration. To move in a new direction will also require that people and firms in the industrialized countries change their wasteful and prodigal consumption patterns to more prudent ones. The fruits of such initiatives will accrue more rapidly if as a global society, we agree to start making fewer children. Much greater investments in social capital, education, and the quality of human well- 
being are needed as well, as mentioned in the Millennium Ecosystem Assessment (2005). We should also internalise the costs of ecological restoration and engineering as part of our collective response to the problems facing global society.

\section{References}

Balmford et al., 2002 A. Balmford, A. Bruner and P. Cooper et al., Economic reasons for conserving wild nature, Science 297 (2002), pp. 950-953.

Brown, 2006 Brown, L., 2006. China Forcing World to Rethink Its Economic Future. Environmental News Network. January. Earth Policy Institute, Washington, DC.

Cairns, 1993 J. Cairns Jr., Ecological restoration: replenishing our national and global ecological capital. In: D. Saunders, R. Hobbs and P. Ehrlich, Editors, Nature Conservation 3: Reconstruction of Fragmented Ecosystems, Surrey Beatty and Sons, Chipping Norton, NSW, Australia (1993), pp. 193-208.

Cairns, 2000 J. Cairns Jr., Setting ecological restoration goals for technical feasibility and scientific validity, Ecol. Eng. 15 (2000), pp. 171-180.

Clewell, 2000 A.F. Clewell, Editorial: restoration of natural capital, Restor. Ecol. 8 (2000), p. 1.

Clewell and Aronson, 2006 A.F. Clewell and J. Aronson, Motivations for the restoration of ecosystems, Conserv. Biol. 20 (2006), pp. 420-428.

Costanza, 1991 In: R. Costanza, Editor, Ecological Economics: The Science and Management of Sustainability, Columbia University Press, New York (1991) 525 pp. Crutzen, 2002 P. Crutzen, Geology of mankind, Nature 415 (2002), p. 23.

Daly and Cobb, 1989 H.E. Daly and J.B. Cobb, For the Common Good. Redirecting the Economy toward Community, the Environment, and a Sustainable Future, Beacon, Boston (1989) 492 pp.

Daly and Farley, 2004 H.E. Daly and J. Farley, Ecological Economics-Principles and Applications, Island Press, Washington DC \& Covelo, CA (2004) 450 pp.

Dasmann, 1972 R. Dasmann, Planet in Peril?, UNESCO-Penguin Books, Middlesex, UK (1972) 135 pp.

Fonseca et al., 2000 M. Fonseca, B. Julius and W. Kenworthy, Integrating biology and economics in seagrass restoration: how much is enough and why?, Ecol. Eng. 15 (2000), pp. 227-237. 
Gadgil, 1995 M. Gadgil, Prudence and profligacy: a human ecology perspective. In:

T.M. Swanson, Editor, The Economics and Ecology of Biodiversity Decline,

Cambridge University Press, Cambridge, UK (1995), pp. 99-110.

Gren, 1995 I. Gren, Costs and benefits of restoring wetlands: two Swedish case studies, Ecol. Eng. 4 (1995), pp. 153-162.

Hackney, 2000 C.T. Hackney, Restoration of coastal habitats: expectation and reality, Ecol. Eng. 15 (2000), pp. 165-170.

Hey et al., 2005 D. Hey, L. Urban and J. Kostel, Nutrient farming: the business of environmental management, Ecol. Eng. 24 (2005), pp. 279-287.

Janzen, 2002 D.H. Janzen, Tropical dry forest restoration: area de conservación Guanacaste, northwestern Costa Rica. In: M.R. Perrow and A.J. Davy, Editors, Handbook of Ecological Restoration: vol. 2. Restoration in practice, Cambridge University Press, Cambridge, UK (2002), pp. 559-584.

Kangas, 2004 P.C. Kangas, Ecological Engineering: Principles and Practices, Lewis Publishers, Boca Raton, FL (2004) 452 pp.

Leopold, 1949 A. Leopold, A Sand Country Almanac and sketches here and there, Oxford University Press, New York (1949) 256 pp.

Lewis, 2005 R.R. Lewis, Ecological engineering for successful management and restoration of mangrove forests, Ecol. Eng. 24 (2005), pp. 403-418.

Millennium Ecosystem Assessment, 2005 Millennium Ecosystem Assessment (MEA), Ecosystems and Human Well-being: Synthesis, Island Press, Washington, DC \& Covelo, CA (2005) 160 pp.

Mitsch and Day, 2006 W.J. Mitsch and J.W. Day Jr., Restoration of wetlands in the Mississippi-Ohio-Missouri (MOM) river basin: experience and needed research, Ecol. Eng. 26 (2006), pp. 55-69.

Mitsch and Jorgensen, 2004 W.J. Mitsch and S.E. Jorgensen, Ecological Engineering and Ecosystem Restoration, John Wiley and Sons, Hoboken, NJ (2004) 411 pp. Mitsch et al., 2002 W. Mitsch, J. Lefeuvre and V. Bouchard, Ecological engineering applied to river and wetland restoration, Ecol. Eng. 18 (2002), pp. 529-541.

Odum, 1994 H.T. Odum, The emergy of natural capital. In: A. Jansson, M. Hammer, C. Folke and R. Costanza, Editors, International Investing in Natural Capital, The Ecological Ecomonics Approach to Sustainability Society for Ecological Economics, Island Press, Washinton, DC and Covelo, CA (1994), pp. 200-232. 
Ruddiman, 2003 W.F. Ruddiman, The Anthropocene greenhouse era began thousands of years ago, Climate Change 61 (2003), pp. 261-293.

Schumacher, 1973 E.F. Schumacher, Small is Beautiful-Economics as if People really mattered, Harper \& Row, London (1973) 352 pp.

Storer, 1968 J.H. Storer, Man in the Web of Life, Signet Books, New York (1968) 360 pp.

Todd et al., 2003 J. Todd, E. Brown and E. Wells, Ecological design applied, Ecol. Eng. 20 (2003), pp. 421-440.

Ton et al., 1998 S. Ton, H. Odum and J. Delfino, Ecological-economic evaluation of wetland management alternatives, Ecol. Eng. 11 (1998), pp. 291-302.

Wackernagel et al., 2002 M. Wackernagel, N.B. Schulz and D. Deumling, Tracking the ecological overshoot of the human economy, Proc. Natl. Acad. Sci. U.S.A. 99 (2002), pp. 9266-9271.

Westman, 1977 W. Westman, How much are Nature's Services worth?, Science 197 (1977), pp. 960-964.

Wilson, 1998 E.O. Wilson, Consilience: The Unity of Knowledge, A.A. Knopf, New York (1998) 332 pp.

Wyant et al., 1995 J.G. Wyant, R.A. Meganck and S.H. Ham, The need for an environmental restoration decision framework, Ecol. Eng. 5 (1995), pp. 417-420.

Corresponding author. Tel.: +33 4676132 84; fax: +33 467412138 . 